\section{気にか るる溶接技術*}

高木乙麿**

A Point of View*

by Otomaro Takagi**

\section{気にかっる溶接技術}

研究開発の計画・実施加らその波及効果の評価とか反 省には上く数字を用いる. 一目りょう然と感じよれるか らだ。即ち効果てき面だが，その反面「数字の魔力」 という一つの「落し穴」があることあ忘れてはなら ない，何故ならば，数字による表現はある一面を物語っ ているに過ぎないと思わねばならないからだ，複雑な技 術上の問題についても決して短絡的ではいけない。

最近，ライシャワー・ハーバード大学教授は「今の日 本は一種のごう慢が忍びよる危険な状態にある」といわ れた。思考にあ軽薄短小型と重厚長大型があり，どちら がいつよか悪いとかは一概に言えない，だが，どちらに しても単細胞的発想は不可・又短期決戦型む不可・むし ろ世紀をもとに考え，実施するぐらいの慎重さが必要で ある、人は常々もっ上広い視野に立って物事を考えなく てはならないということだと思う。そこで溶接技術に携 わる者の位置する座標はよ゙んなものか考え直してみよう。

三百兆円国家が欧米の労働者より年間三百から四百時 間余計に㗢き，主食米の生産が三兆円に対し，半導体の それは二兆八干億円では過剩生産気味ではないのか。あ ともと設備投資と生産原価の関係は，前者が大きくなれ 代後者は下がる，今は経済成長より文化にもっ上力を注 ぐことが大事ではなかろうか.

溶接の大先翟の一人である岡田実元阪大総長は「文化 とは個々別々のあのを結合することにある」といわれた。 溶接技術の文化（文明）に対する重要性を認識しなくて はならない。その理念があてないとしたら自主性はない と云えよう。

\section{加工法の一つとしての溶接技術}

前述の如く個々バラバラの各部品を組立結合して一つ

${ }^{*}$ 原稿受付 昭和60年10月 5 日

**特別員 鉄鋼短期大学客員教授 工博 Special Member, Guest Professor of Iron and Steel Technical College, Dr. Eng.
の目的を果す手法としての基本理念に基くのが溶接技術 であり，コスト莪（低）減の効果む他の接合法之較べて 格段の利点がある. しかしいつまでも「○○の一つ覺え」 のようではいりない，八イ・テク時代の溶接技術を考え ると長期展望が必要だ，その第一は素材産業革命化に対 応する溶接技術である.

世は将に重化学工業から先端技術産業時代へと大きく 変化している. 今迄の技術者の最大の役割は巨大工場を いか効率よく稼動させて，マスプロ製品の製造コスト をよ゙れだけ下げるかにあったが，八イ・テク時代では様 相が全く異る. 外国の優れた技術を睡入し改良して生産 を向上させる時代は既に過ぎ去ってしまった。先進技術 の入手はすこぶる困難であるか，不可能に近い，乙れか らの商品は必然的にオリジナリティに富むあので多品種 少量生産となる，そのために必要なのは「技術」である。 世界のどこにもないオリジナル技術をどれだけ持って, しかも今後とも開発していくだけの力を持っているかが 勝負であるととを忘れてはならない。

八イ・テク時代に技術開発の教科暮はない，みずからの 力で技術を生みだしていかなければならない，そ抽才 リジナル技術である，広辞苑をみるとオリジナリティと は「独創・独創力・独創性・創意」とあり，又「独創」 とは「模做によらず自分一個の考えで独得の創意をあら わすこと」と記されている.

て〉で，オリジナル技術の源流例の一つに今日の松下 電器産業の松上幸之助氏が若い時化開発した自転車用ラ ンプがあり，その二はブリジストンの創業者石橋正二郎 氏の足袋の底にゴムを貼りつけた地下足袋の開発であっ たといわれる．上記の二企業の今日の隆盛の基は，乙の 開発思想を正しく継承して来ているに外ならない。乙う みてくると，オリジナル技術とは単なる独創技術ではな く，企業なり集団の理念亡不可分の関係にあり，そのフィ ロソフィの具現化ではなからうか．時代の先取りをする ことも忘れてはならない。

1970年時代にドイッで生れた自動車工業はイギリスに 移りややがてアメリカへの繁栄が移行し，現在は日本が 最先端を進んでいる現状だ。乙れは1980年代のエレクト ロニクス産業の台頭であり，1990年代ではてのエレクト ロニクス産業が主流になると考えられている．しかむ 2000 年になっても日本の自動車工業はてのエレクトロニクス 産業のお险で最先端を突走るだろうとまでいわれている。 その理由は，ロボットと新素材とエレクトロニクスの出 現である、ロボットは労働形態を変え，新素材は軽量化 と機能化を可能にし，車の設計を変えるし，エレクトロ ニクス技術は自動車に新しい機能を附与するようになる 
からだ，言い換えれば，自動車工業一つを採り上げてあ； 新菜材とエレクトロニクスをバネにして遂げられている ということである.

ての両者は溶接技術にとって屯重要な課題であるとい えまいか.

\section{情報化時代と溶接技術}

ME (自動) 化が近代工業の花形で，IC や LSI は前 にも述べた生産過剩気味ではあるが，その忘用として計 算・記憶・制御を備えたプロセッサーや，乙れに入力装 置を加えたマイクロ・コンピュータを組込んだ機器，ロ ボット, ワープロ, パソコン, ファクシミり etc., い つれあ企業に大いにとり入れられている. しかし「算数 能力」と「計算能力」は異なる一一即ち計算能力で算数 能力を判断はできない，との事は何によらず「基本」を 身につけることが大切だと教えている。

溶接技術者だけでなく同研究者も基本を先づ究め，しっ からした基盤に立って初めて成果を期待できるものだ。 独りで図書館に入って既存のデータを集めることはむう 不可能な程の情報過多の時代である. 学者も研究者も情 報か勝負で，どてでどんな研究が進んでいるのかを知ら なければ先陣争いに敗れてしまう。また基礎研究は地道 で且つ大事であるが，一般的に言って，日本はこの基礎 研究が遅れているといわれる。応用研究とか実用研究は 先端技術として突出してはいるが。

そてでオンラインで一目りょう然となる DBN (Data Base Network) が最近発足した. てれからはこのシス テムを利用して溶接工学の基礎研究を進めなくてはなら ない，猪瀬博東京大学文献情報センタ長は「データ・ベー スはぬかみそと同じなんです。漬り込まないと味がでな いし，年中かき混ぜていないと使いものにならない，そ れをやるのはひたすら人の力です，データ・ベースの編 集，更新は最終的には人間がやらないとどうしょうあな いのです.」と言っている由である. 各地の大学（東京 工大，名大，阪大，京大，九大は既に利用可能）とはま だ共用できる状況ではないにしても将来は私立大学とも オンライン化されるてとを期待したい，そうして溶接技 術の ME 化が一般的になるためには各研究者・技術者 とを問わず誰すがコンピュータに関する基本となる技術 を修得しなくてはならない。

ての事が先ず溶接技術者全部が老若を問わず今すぐ真 剣に取り組まなくてはならないと考えられる.

\section{トータル・エネルギ・システムと溶接技術}

今はエネルギの有効利用が特に大きな声で叫ばれてい
る.エネルギが有限であるてとは万人が承知してはいる が，実感として身についていないともいえる.

溶接技術にも熱源を必要とする。一番多く用いられて いるアーク溶接でも，アーク熱を利用するがアーク光は 邪魔もの扱いされている，保護具として遮光ガラスを必 要とする，溶接のために用いる熱エネルギは有効化を計っ ているが，乙の光エネルギについては利用されていない． 永い間に亘ってアーク溶接は加工技術の一翼を担って来 てはいるが，今とそェネルギは21世紀の繁栄のために大 切にしたいむのである.

大口のエネルギ消費者の一つである素材産業たる製鉄 会社む生産の抑制だけを目標とせず，むはや板や棒鋼， 鋼管だけを造っている時代ではなくなった．各企業とむ

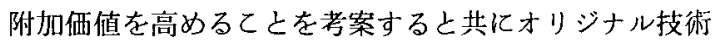
の開発に乗り出している.

レーザ (Light Amplification by Stimulated Emission of Radiation) の応用は目に見えない赤外線 を使う $\mathrm{CO}_{2}$ レーザなどと紫外線のエキシマ・レーザな ぞ新しい化学エネルギとしての研究が進められていて, 熱エネルギとしての $\mathrm{CO}_{2}$ レーザでの容量 $20 \mathrm{~kW}$ 位の あのは溶接への活用化が既に実現している。眼に見えな いとはいえ光エネルギの一つであるレーザ溶接技術の実 用化を今より搪げることも大切だが，こっで発想の転換 をはかり, 単に労働力の変換だけのロボットではなく, 広い意味でのロボット化をはかる上でもっと有効なト一 タル・エネルギ・システムの導入を考えた溶接技術の発 展か待たれるわけである.

\section{溶接芰街発展のためのチーム・プレー}

西欧（特にフランスではそれが顕著）では，ひとりの 天才が独創技術を発明及至は発見し，然る後保企業集団 で利用をはかるのが通例だが，日本では組織で，チーム。 プレーで各企業が確固たる企業理念のもとに発明・発見 して知識集約型の創造集団として歩きはじめるのが一般 的だ．欧米人はよく「日本人にはオリジナル技術はなく 物マネだ」と声高に言われるが，それは䛊解で，物マネ ではなく夫々のチーム・ワークによる研究開発があたら したあのである.ひとりの天才よりも10人のチームの力 の方が優っている．特に現代はそうした時代になりつ〉 ある.

以上とりとめあないことを述べてきたが，要するに溶 接技術はわれわれ人類社会に文明開花をむたらす重要な 手段の一つであるという認識を共有し，抢互いに協力し 合い努力することが，今正問われているのだと言いた い. 